\title{
LEADERSHIP EFFECTIVENESS IN HUMAN RESOURCE MANAGEMENT
}

\author{
Rima Mammadova \\ University of Pecs, Pecs, Hungary
}

\section{Introduction}

HRM and Leadership are the main researched topics in the organizational science (Russell, et al., 2018) and for many years, they have been separately researched (Vermeeren, Kuipers and Steijn, 2014). Currently, interest in interaction between leadership styles and HRM practices and activities has grown. Despite the plenty of research on Leadership and HRM separately, there are scarce number of researches have been conducted on interaction of these two areas. There are also various opinions between HRM and Leadership researchers on the relationship and interaction between these two areas. In some HR literature, researchers consider the role of leaders are passive and they think that leaders are discoursers and enactors of HRM policies (Buengeler, Leroy and De Stobbeleir, 2018). However, in some leadership literature, researchers see the role of leadership in HRM practices very important and their interactions very useful (Badrani, Madya and Akil, 2015).

Human Recourses play a key role in development and sustainable growth of organizations. When looking through the history of HRM it can be seen that the role of HRM turn to strategic from personal. In our days, top management of the organizations accept that they can achieve their strategic goals through HRM and 
pay more attention to the improvement of their HRM department. They understand that effective implementation of HRM will increase the performance of individuals at the same time organization.

There are different definitions of leadership and its effectiveness due to its complexity. Nahavandi (2012) wrote that researchers define leadership by considering different aspects of leadership. Northouse (2016) wrote that leadership has four components: it is a process; it influences followers; it happens in a group; it involves common goals. Bringing together these four components, he defines leadership as "a process whereby an individual influences a group of individuals to achieve a common goal." (Northouse, 2016, p. 6).

The main important topics in Leadership are its effectiveness and measurement. The definition of leadership effectiveness is also complex as a definition of leadership itself. Different models in leadership describes leadership effectiveness and its measurements differently. In this paper, some of them were introduced.

HR manager must balance the relationship between organization and its employees in order to achieve the goals and strategies of the organization, as well as the goals and needs of employees (Ahammad, 2017). Leader also must understand the goals and strategies of the organization and identify the steps to achieve strategic goals (Belias and Koustelios, 2014). From this similarity, it can be concluded that HR manager can use leadership to identify and realize the objectives of the organization. It is known that every managers, HR managers, CEOs have their own management styles, however to add leadership skills and enhance them will manage the occurred changes which involve risks and ambiguity within and outside of the organizations effectively and efficiently (Mehmood and Arif, 2011). Work performance inside the organization will increase by using qualified leadership and individual motivation (Porter, Smith, and Fagg, 2006)

The goal of this paper is to investigate to what extent the main types of leadership impact the organization success in the area of human resources management. This paper is organized as follows: first, the relevant literature on HRM, Leadership and Leadership effectiveness was reviewed; and second, the different opinions on which type of leadership is more effective in HRM was explored. To achieve its goal, the research systematically reviewed peer reviewed articles published in reputable journals. 


\section{Human Resource Management (HRM) and Leadership}

Human Recourses play a key role in development and sustainable growth of organizations. Therefore, top management of the organizations accept that they can achieve their strategic goals through HRM and pay more attention to the improvement of their HRM department. Armstrong, M. (2009, p.4) defined Human Resource Management (HRM) as "a strategic, integrated and coherent approach to the employment, development and well-being of the people working in organizations." According to Beer, M. et al., (1984, p. 1) "Human resource management involves all management decisions and action that affect the nature of the relationship between the organization and its employees - its human resources."

The evaluation of HRM has been discussed by an extensive literature and when doing literature review on it, it can be seen that its name has been changed throughout the history due to the social and economic activities (Ahammad, T., 2017). It was called as Personal Management, Industrial Relations, and Human Resource Management. There are different thoughts on establishment and development of HRM. Kaufman, B.E., (2014) in his study wrote that the beginning history of HRM depends on the definition and concept. He also mentioned that if approach HRM as it covers all employment relationships and directs the work of others, then the history goes back to the human civilization where thousands of workers were coordinated (Kaufman, B.E., 2014). Dulebohn et al., (1995 see Kaufman, B.E., 2014) noted that HRM originated out of industrial welfare work, scientific management and industrial psychology. Jamrog and Overholt (2004) mentioned in their article that the first personnel departments were established during the 1920s and employed specialists to oversee areas like employment, employee welfare, wage setting, safety, training, and health.

Between 1930-1960, the field of HRM started to develop due to the social, economic and technological activities, and top management paid more attention to it and the modern HR professional was born (Jamrog and Overholt, 2004). In the early 1980s, HRM term started to use in a different meaning from Personal Management and scholars and practitioners started to talk about HRM as an innovation (Kaufman, B.E., 2014). By the mid-1990s, the term of strategy started to appear in the field of HRM field and scholars and practitioners started to use Strategic HRM (Patrickson and Hartmann, 2001).

It is a common belief that employees are the most important asset in the organization (Sarip and Royo, 2014). However, Belcourt (2009 see Sarip and Royo, 2014) wrote in his study that HR practices are more important than employees in the organization. He mentioned that workers who currently 
employed may quit and new workers will be employed, but HR practices will remain (Belcourt, 2009 see Sarip and Royo, 2014). Budhwar (2000) wrote that HRM will be more effective when the importance of HR is recognized and accepted by the top management.

Top management must give the power and equal resources to the HR departments. In this case, HR departments can act strategically (Mitsuhashi et al., 2000). Therefore, top management must pay more attention to HRM's integration with the firm's strategy (Wei and Lau, 2005). They understand that effective implementation of HRM will increase the performance of individuals at the same time organization. The various discussions about the importance of HR bring us to the question that how leadership can be used in development and sustainable growth of organizations. Researchers conducted several studies in order to answer such kind of questions.

There are different definitions of leadership and its effectiveness due to its complexity. Nahavandi (2012, p.3) wrote that researchers define leadership by considering different aspects of leadership. "Some define leadership as an integral part of group process (Green, 2002; Krech and Crutchfield, 1948). Others define it primarily as an influence process (Bass, 1960; Cartwright, 1965; Katz and Kahn, 1966). Still others see leadership as the initiations of structure (Homans, 1950) and the instrument of goal achievement. Several even consider leaders to be servants of their followers (Greenleaf, 1998)." (Nahavandi, 2012, p.3). Northouse (2016) wrote that leadership has four components: it is a process; it influences followers; it happens in a group; it involves common goals. Bringing together these four components, he defines leadership as "a process whereby an individual influences a group of individuals to achieve a common goal." (Northouse, 2016, p. 6)

Leadership, and the studies on it, has roots in the beginning of civilization (Stone and Patterson, 2005). The study of leadership became more important during the Industrial Revolution and researchers used scientific methods to understand and foresee leadership effectiveness by defining and evaluating leadership characteristics (Nahavandi, 2012). Stone and Patterson (2005) mentioned that "theorists set two stage namely "classical management theory" and "scientific management." Classical theorists focused on the design of the total organization while scientific managers focused on the systematic management of individual jobs." (Stone and Patterson, 2005, p.2). Morgan (1997 see Stone and Patterson, 2005) also mentioned that despite the classical and scientific approaches were different, both of them had the same goal: organization must operate efficiently in order to achieve the highest level of productivity.

Nahavandi (2012) in his book divided the history of the modern scientific approach to leadership into three general eras: The Trait Era, The Behavior Era, 
and The Contingency Era. He explained each era as following (Nahavandi, 2012, pp. 63-65):

In the Trait Era (late 1800s to mid-1940s), there was a belief that leaders are born rather than made and innate qualities shape human personality and behavior. In this era, researchers were influenced by the belief in the power of personality and other innate characteristics and they started to hunt for leadership traits and they defined and observed existing leaders and followers and gathered detailed demographic and personality information about them (ibid.).

Researchers started to investigate behaviors, rather than traits, as the source of leader effectiveness in the mid-1940s. During the World War II, leaders were needed and the trait approach was not enough to train and make leaders. Therefore, a new era namely "the Behavior Era" (mid-1940s to early 1970s) started. The behavior approach emphasized what an effective leader does (ibid.)

The behavior approach also was not success and it helped other researchers to define a comprehensive approach to understanding leadership. Thus, The Contingency Era (early 1960s to present) started. The primary assumption of the contingency view is that the personality, style, or behavior of effective leaders depends on the requirements of the situation in which the leaders find themselves (ibid.).

HR manager must balance the relationship between organization and its employees in order to achieve the goals and strategies of the organization, as well as the goals and needs of employees (Ahammad, 2017). Leader also must understand the goals and strategies of the organization and identify the steps to achieve strategic goals (Belias and Koustelios, 2014). From this similarity, it can be concluded that HR manager can use leadership to identify and realize the objectives of the organization. HR manager can implement leadership development strategies (reform programs, career development paths, etc.) (Berman, 2015) in order to reach the organization strategic goals. Leroy et al (2018) with his colleagues in their paper discussed the possible combination of HRM and leadership styles and found that to influence the others HRM and Leadership styles use different values. However, HRM and Leadership styles can fit on value aspect (Leroy et al., 2018). Regarding the influence aspect of Leadership and HRM, Leroy et al (2018) mentioned that in leadership a person, leader influence to the individual or group, but in HRM a system and processes influence to the people.

Van Wyk (1989 see Mehmood and Arif, 2011) argued that HRM creates an environment where employees strive to do their best, where opportunities are equally distributed, where initiatives are encouraged and the conditions for success are created. New paradigm namely shared leadership and a shared vision 
(Mehmood and Arif, 2011) can play an important roles in creating such environment. Shared leadership is leadership that combines two or more leaders in one organization (Badrani, Madya and Akil, 2015). By using leadership, HR manager can decrease the stress among employees, increase their confidence, and encourage them to participate in decision making process as well as to increase their performance (Chuang, Jackson and Jiang, 2016). Employees will be empowered, encouraged and supported in their personal and professional growth inside the organization (Stone and Patterson, 2005).

Leadership and HRM researchers accept that employees are the most valuable assets of the organization. Leroy et al (2018) showed seven possibilities how HRM and Leadership can interact with each other: independence, enactment, supplementary fit, synergistic fit, complementary fit, perceptual filters, and dynamic fit (for more information see Leroy et al., 2018). In terms of sustainable development of the company, Leadership and HRM can also interact with each other. HR managers can use leadership commitment to sustainability in order to break down the barriers, such as past practices, old ideas and cultural frameworks (Gloet, M., 2006) and encourage employees to be more innovative and creative. As leadership supports HRM, HRM also supports leadership. It helps the communication process between leaders and employees with activities such as staffing and training which leaders use to transfer their vision (Vermeeren, Kuipers and Steijn, 2014).

\section{Leadership Effectiveness}

The definition of leadership effectiveness is also complex as a definition of leadership itself. Researchers from different areas, such as business, philosophy try to answer a question what is leadership effectiveness for many years. Despite this, scholars can easily answer question what is a bad leadership. Different models in leadership describes leadership effectiveness differently. Generally, researchers assess leadership effectiveness by its influence effects on an individual, group/team or and organizations (Yukl, 2013). Some researchers define the leadership effectiveness in terms of group performance which means if the team's performance is well, then their leader was effective, other researchers consider follower satisfaction as a main indicator of defining leadership effectiveness, and still others connects leadership effectiveness with the successful implementation of change in an organization (Nahavandi, A., 2015). Yukl (2013) wrote that characteristics of leaders, followers, and the situation are variables for understanding leadership effectiveness. Bertocci (2009) mentioned in his book that relationship between leaders and their followers and involved circumstances influence leadership effectiveness.

Nahavandi (2015) summarized leadership effectiveness when the followers achieve the goals, act together well and fit the changing demands from outsides. 
He also mentioned three elements of leadership effectiveness: 1. Goal achievement, which includes meeting financial goals, producing quality products or services, addressing the needs of customers, and so forth; 2. Smooth internal processes, including group cohesion, follower satisfaction, and efficient operations; 3. External adaptability, which refers to a group's ability to change and evolve successfully (Nahavandi, 2015, p. 27).

It is not easy to evaluate the leadership effectiveness due to the various type of measurements. However, Yukl (2013) mentioned four types of measurements. First type is the extent to which the performance of the team or organizational unit is enhanced and the attainment of goals is facilitated. As performance measures he specified sales, net profits, profit margin, market share, return on investment, return on assets, productivity, cost per unit of output. The second type measurements are follower attitudes and perceptions of the leader which are measured with questionnaires or interviews. The third type of measurement is the leader's contribution to the quality of group processes, as noticed by followers or by outside observers. The last measurement is the extent to which a person has a successful career as a leader (Yukl, 2013, p.9).

It is accepted that every managers, HR managers, CEOs have their own management styles, however to add leadership skills and enhance them will manage the occurred changes which involve risks and ambiguity within and outside of the organizations effectively and efficiently (Mehmood and Arif, 2011).

\section{Leadership types and their role in HRM}

Different types of leadership such as autocratic, democratic, strategic, transformational, transactional and laissez-faire leadership were/are offered to leaders to influence their followers. Nahavandi (2012) wrote that in democratic leadership leaders confer with their followers and let them to actively participate in the decision-making processes and in autocratic leadership leaders make decision themselves and not let their followers to participate in it. Strategic leadership define as "the ability to anticipate, envision, maintain flexibility, and empower others to create strategic change as necessary." (Hitt et al. 2009, p. 340). The various discussions about the importance of HR bring us to the question that how leadership can influence the effectiveness of HRM. In this part, three types of leadership - Transactional, Transformational and Laissez-Faire Leadership will be discussed in terms of their effectiveness in HRM. 


\section{Transactional Leadership in HRM}

Antonakis et al. (2003, p. 265) defined transactional leadership as "an exchange process based on the fulfillment of contractual obligations and is typically represented as setting objectives and monitoring and controlling outcomes." Mainly focus of transactional leadership is cognitions of followers who are encouraged to implement tasks in appropriate ways and standards by the transactional leader and who are dependent on the leader's decisions (Delegach et al., 2017). Transactional leaders evaluate accomplishments and breakdowns and use monetary rewards for implemented performance (Delegach et al., 2017). Transactional leadership appears through three factors: contingent reward, management by exception active and management by exception passive (Mehmood and Arif, 2011). Liu et al., (2003) with his colleagues in their research paper matched leadership styles with employment modes. They found out that transactional leadership style is more effective for job-based employee group (Liu et al., 2003). Researches on the effects of transformational leadership on individual performance and organizational outcomes have been shown that there is a positive impact among them (Zhu, Chew and Spangler, 2005). This style of leadership creates motivating and trusting work environments inside the organizations (Zhu, Chew and Spangler, 2005).

\section{Transformational Leadership in HRM}

Antonakis et al. (2003, p. 264) defined transformational leaders as "are proactive, raise follower awareness for transcendent collective interests, and help followers achieve extraordinary goals." Transformational leadership helps followers to be creative and to face with various challenges and problems which lead them to the future growth and development and create such circumstances where employees perceive organizational goals as their own (Delegach et al., 2017). This style of leadership highlight the importance of motivation and rewards in order to get balance between the goals of organization and the personal goals of employees (Delegach et al., 2017). It is appeared through four leadership factors: Individualized consideration, intellectual stimulation, inspirational motivation and idealized influence (Phaneuf et al., 2016).

According to the research, transformational leadership style has a positive impact on the used HR practices in the organizations (Vermeeren, Kuipers and Steijn, 2014). With the help of technology and motivation, HR manager who uses transformational leadership style makes knowledge employees from ordinary ones and increases the employees' performance (Khudeir, H. 2016). Liu et al., (2003) and his colleagues also found out that transformational leadership style are more effective for alliances employee group. Bass (1998 see Mehmood and Arif, 
2011) wrote that transformational leadership style has an important impact in foreseeing satisfaction of employees with their leaders.

\section{Laissez-Faire Leadership in HRM}

According to Antonakis et al. (2003, p. 265), laissez-faire leadership "represents the absence of a transaction of sorts with respect to leadership in which the leader avoids making decisions, abdicates responsibility, and does not use their authority." Leaders provide information for their followers, however they provide little guidance and evaluation in laissez-faire leadership and consequently performance becomes low quality (Nahavandi, 2012). This style of leadership is considered the most passive and unproductive form of leadership (Antonakis et al., 2003). Main characteristics of laissez-faire leaders are: rejecting to take on responsibilities; delaying to solve important questions; avoiding to take decisions and renouncing to have influences (Mehmood and Arif, 2011).

Mehmood and Arif (2011) in their research assessed perception of teaching staff about transformational, transactional and laissez-faire leadership styles of their HRM executives in Pakistan. They found that laissez-faire leadership style was most dominant in HRM executives than transformational and transactional leadership styles and according to them, universities administration have conducted special trainings in order to improve leadership behavior, because laissez-faire leadership style does not accommodate in present changing world (Mehmood and Arif, 2011). Generally, laissez-faire leadership has been accepted with negative results; however, Yang (2015) in his work proved the opposite. He looked at laissez-faire as non-involvement of leadership and mentioned that leaders can choose laissez-faire leadership as a strategic behavioral choice and by this way followers will be more independent and high self-determination. In noninvolvement of laissez-faire leadership, between leaders and their followers will be a positive supervisory trust and followers will be a positive self-motivated (Yang, 2015). Chaudhry et al., (2012) also found a positive and important relationship between laissez faire leadership and motivation.

\section{Limitations}

There are plenty of researches, on Leadership and its styles and HRM and its practices separately. Despite this, scarce number of researches have been conducted on interaction of these two areas. Therefore, it was not able to collect as much as articles in order to make a deep analyze. Especially, there was a lack of research articles on the interaction of laissez-faire leadership and HRM. 


\section{Conclusion}

In a highly competitive world and the latest technological achievements, organizations must possess highly motivated and talented employees in order to compete with other organizations. The organizations establish HR department in order to improve the performance of their employees and to manage and solve unexpected changes and any kind of challenges that can happen inside the organizations. Referred to the above-mentioned literature, it can be concluded that the interaction between Leadership and HRM is necessary to manage the employees and any kind of challenges and changes.

As mentioned before each HR managers have their own management style for managing employees and situation. Adding leadership skills in their managerial skills, HR managers can handle easily any kind of changes at the same time improve performance and motivation of the employees. Above three types of leadership -transactional, transformational and laissez-faire leadership have been explored in terms of their effectiveness in HRM. Referred to the relevant literature, it can be concluded that all three types of leadership can be effective in HRM. However, HR managers have to be more careful when apply them in the situations due to their characteristics.

Refer to the existing literature on the effectiveness of transactional, transformational and laissez-faire leadership in HRM, it can be also concluded that this topic is under the little attention. It is suggested to conduct on researches on how effectiveness of transactional, transformational and laissez-faire leadership in HRM can be measured. 


\section{References and notes:}

Ahammad Taslim. "Personnel Management to Human Resource Management (HRM): How HRM Functions?.” Journal of Modern Accounting and Auditing 13.9 (2017): 412-420.

Antonakis John, Bruce J. Avolio, and Nagaraj Sivasubramaniam. "Context and leadership: An examination of the nine-factor full-range leadership theory using the Multifactor Leadership Questionnaire." The leadership quarterly 14.3 (2003): 261-295.

Armstrong Michael. Armstrong's Handbook of Human Resource Management Practice. London and Philadelphia. Kogan Page. 2009.

Badrani Mohamed RAK, Madya, and Sharifah Meriam Binti Syed Akil. "Impact of shared leadership on human resource management, organizational behavior and job performance at Almadar Aljadeed Company Tripoli-Libya." International Journal of Applied Research 1.13 (2015): 720-725.

Beer Michael, Spector Bert, Lawrence R. Paul, Mills D. Quinn, and Walton E. Richard. Managing human assets. The Free Press, New York. 1984.

Belias Dimitrios, and Athanasios Koustelios. "The impact of leadership and change management strategy on organizational culture." European Scientific Journal 10.7 (2014): pp.451-470.

Berman Evan M. "HRM in development: Lessons and frontiers." Public Administration and Development 35.2 (2015): 113-127.

Bertocci David I. Leadership in organizations: There is a difference between leaders and managers. University Press of America, 2009.

Budhwar S. Pawan. "Strategic integration and devolvement of human resource management in the UK manufacturing sector." British Journal of Management 11.4 (2000): 285-302.

Buengeler Claudia, Hannes Leroy, and Katleen De Stobbeleir. "How leaders shape the impact of HR's diversity practices on employee inclusion." Human Resource Management Review 28.3 (2018): 289-303.

Chaudhry Abdul Qayyum, and Husnain Javed. "Impact of transactional and laissez faire leadership style on motivation." International Journal of Business and Social Science 3.7 (2012): 258-264.

Chuang Chih-Hsun, Susan E. Jackson, and Yuan Jiang. "Can knowledge-intensive teamwork be managed? Examining the roles of HRM systems, leadership, and tacit knowledge." Journal of management 42.2 (2016): 524-554.

Delegach Marianna, Kark Ronit, Katz-Navon Tal, and Van Dijk Dina. "A focus on commitment: The roles of transformational and transactional leadership and self-regulatory focus in fostering organizational and safety commitment." European Journal of Work and Organizational Psychology 26.5 (2017): 724-740.

Gloet Marianne. "Knowledge management and the links to HRM: Developing leadership and management capabilities to support sustainability." Management Research News 29.7 (2006): 402-413.

Hitt Michael A., Duane R. Ireland, and Robert E. Hoskisson. Strategic management concepts: competitiveness and globalization. Cengage Learning. 2009.

Jamrog Jay J., and Miles H. Overholt. "Building a strategic HR function: Continuing the evolution." Human resource planning 27.1 (2004): 51-62

Kaufman Bruce E. "The historical development of American HRM broadly viewed." Human Resource Management Review 24.3 (2014): 196-218.

Khudeir Hamzeh. "The Effect of Blending HRM Transformational Leadership Style with HRM ICT Expertise Leadership Style on Creating New HRM Strategy That Enable National Companies to Go Global. Evidence from Jordan: Sayegh 
Group and Hikma Pharmaceutical Corporation.” Journal of Education and Practice 7.31 (2016): 108-112.

Leroy Hannes, Jesse Segers, Dirk Van Dierendonck, and Deanne Den Hartog. "Managing people in organizations: Integrating the study of HRM and leadership." Human Resource Management Review 28 (2018): 249-257.

Liu Wei, David P. Lepak, Riki Takeuchi, and Henry P. Sims Jr. "Matching leadership styles with employment modes: Strategic human resource management perspective." Human resource management review 13.1 (2003): 127-152.

Mehmood Zafar Ul Islam, and Muhammad Irfan Arif. "Leadership and HRM: Evaluating new leadership styles for effective human resource management." International Journal of Business and social science 2.15 (2011): 236-243.

Mitsuhashi, Hitoshi, Hyeon Jeong Park, Patrick M. Wright, and Rodney S. Chua. "Line and HR executives' perceptions of HR effectiveness in firms in the People's Republic of China." International Journal of Human Resource Management 11.2 (2000): 197-216.

Nahavandi Afsaneh. The art and science of leadership. Pearson Education, Inc. 2012.

Nahavandi Afsaneh. The art and science of leadership. Pearson Education, Inc. 2015.

Northouse Peter G. Leadership: Theory and practice. Sage publications, 2016.

Patrickson Margaret, and Linley Hartmann. "Human resource management in AustraliaProspects for the twenty-first century." International Journal of Manpower 22.3 (2001): 198-206.

Phaneuf Julie-Élaine, Jean-Sébastien Boudrias, Vincent Rousseau, and Éric Brunelle. "Personality and transformational leadership: The moderating effect of organizational context." Personality and Individual Differences 102 (2016): 30-35.

Porter Keith, Paul Smith, and Roger Fagg. Leadership and management for HR professionals. Biddles Ltd, Norfolk, 2006.

Russell Zachary A., David S. Steffensen, B. Parker Ellen III, Liwen Zhang, John D. Bishoff, and Gerald R. Ferris. "High performance work practice implementation and employee impressions of line manager leadership." Human Resource Management Review 28.3 (2018): 258-270.

Sarip Azlineer, and Mohamad Abdillah Royo. "Strategic HR in higher educational institutions in Malaysia and Denmark." International Journal of Trade, Economics and Finance 5.1 (2014): 60-64.

Stone A. Gregory, and Kathleen Patterson. "The history of leadership focus." In Servant leadership research roundtable. 2005: 1-23.

Vermeeren Brenda, Ben Kuipers, and Bram Steijn. "Does leadership style make a difference? Linking HRM, job satisfaction, and organizational performance." Review of Public Personnel Administration 34.2 (2014): 174-195.

Wei Li-Qun, and Chung-Ming Lau. "Market orientation, HRM importance and competency: Determinants of strategic HRM in Chinese firms." The International Journal of Human Resource Management 16.10 (2005): 19011918.

Yang Inju. "Positive effects of laissez-faire leadership: conceptual exploration." Journal of Management Development 34.10 (2015): 1246-1261.

Yukl A. Gary. Leadership in organizations. Pearson Education Inc. 2013.

Zhu Weichun, Irene KH Chew, and William D. Spangler. "CEO transformational leadership and organizational outcomes: The mediating role of humancapital-enhancing human resource management." The leadership quarterly 16.1 (2005): 39-52. 


\title{
XÜLASכ
}

\section{İnsan resurslarının idarə edilməsində liderlik effektivliyi}

\author{
Rima Məmmədova \\ Peç Universiteti, Peç, Macarıstan
}

İnsan Resurslarının İdarəedilməsi və Liderlik təşkilatçılıq elmində əsas tədqiqat mövzularındandır (və illərlə ayrıca araşdırılır.) Hal-hazırda liderlik üslubları ilə İnsan Resurslarının İdarəedilməsi təcrübələri və fəaliyyətləri arasında qarşılıqlı əlaqəyə maraq artmışdır. Bu iki sahənin qarşılıqlı əlaqəsi ilə bağlı çoxsaylı tədqiqatlar aparılmışdır.Bu araşdırmanın məqsədi əsas liderlik növlərinin İnsan resurslarının idarə edilməsi sahəsində təşkilati uğurlarına nə dərəcədə təsir etdiyini araşdırmaqdır. Bu yazı aşağıdakı kimi təşkil edilmişdir: əvvəlcə İnsan Resurslarının İdarəedilməsi , Liderlik və Liderlik effektivliyi ilə bağl1 ədəbiyyatlar nəzərdən keçirilir; İkincisi, İnsan Resurslarının İdarəedilməsində hansı liderliyin daha effektiv olması ilə bağlı fərqli fikirlər araşdırılır.

Bu məqsədə çatmaq üçün, müəllif tədqiqat nüfuzlu jurnallarda dərc olunan həmyaşıd məqalələri sistematik şəkildə nəzərdən keçirdi.Nəzərə alsaq ki, hər bir İR menecerinin işçilərin idarəetmə və liderlik bacarıqlarından necə istifadə etməsi ilə bağlı öz idarəetmə tərzi var. Buna görə də, bu yazıda, ÜRM-də effektivliyi baxımından üç növ liderlik, transaktiv, transformasiya və laissez-faire liderliyi araşdırılır.IRM və Liderlik, xüsusilə də laissez-faire rəhbərliyi və İRM arasında qarşılıqlı əlaqə kifayət deyil. Başa düşmək olar ki, bu məsələ İRM -də əməliyyat, transformasiya və laissez-faire rəhbərliyinin səmərəliliyinə az diqqət çəkir. İnşaat Resursları İdarəetməsində əməliyyat, transformasiya və lissez-faire rəhbərliyinin effektivliyini necə ölçmək barədə araşdırmalar aparılmayacaqdır.

Açar sözlər: İnsan Resursları İdarəedilməsi, Liderlik, Liderliyin Səmərəliliyi, Transaksiya,Transformasiya və Laissez-Faire Liderliyi 


\section{PEЗЮМЕ}

\section{Эффективность лидерства в управлении человеческими ресурсами}

\section{Рима Мамедова \\ Печский Университет, Печ, Венгрия}

УЧР (Управление Человеческими Ресурсами) и лидерство являются ключевыми темами исследований в области организационной науки (и изучались отдельно в течение многих лет). Настоящее время вырос Интерес к взаимодействиям между стилями лидерства и практикой и деятельностью УЧР. Были проведены многочисленные исследования, связанные с взаимодействием этих двух областей. Целью данного исследования является изучение степени влияния на организационные успехи ключевых типов лидерства в сфере управления человеческими ресурсами. Эта статья организована следующим образом: во-первых, рассмотрена литература по УЧР, лидерству и эффективности лидерства; Во-вторых, исследуетс различные взгляды на то, какое лидерство наиболее эффективно в УЧР. Для достижения этой цели в исследовании систематически анализировались рецензируемые статьи, опубликованные в авторитетных журналах. Учитывая, что у каждый менеджер по персоналу имеет свой собственный стиль управления с точки зрения того, как сотрудники используют свои управленческие и лидерские навыки. Поэтому в данной статье рассматриваются три типа лидерства, влияющие на эффективность УЧР: транзакционное, трансформационное и «laissez-faire» лидерство. Отношения между УЧР и Лидерством, особенно взаимосвязь между «laissez-faire» лидерством и УЧР, недостаточно. Понятно, что в этом вопросе мало внимания уделяется работе с персоналом, трансформации и эффективности управления «laissez-faire» лидерства. В управлении строительными ресурсами не будет проводиться исследования о том, как измерить эффективность операционного, трансформационного, «laissez-faire» лидерства и эффективного управления.

Ключевые слова: Управление человеческими ресурсами, лидерство, эффективность лидерства, Транзакционность, Трансформация и лидерство Laissez-Faire 